\title{
Woody Vegetation and Soil Characteristics of Residential Forest Patches and Open Spaces along an Urban-to-Rural Gradient
}

\author{
Benjamin L. Reichert ${ }^{1}$, Sharon R. Jean-Philippe ${ }^{1}$, Christopher Oswalt ${ }^{2}$, Jennifer Franklin1, \\ Mark Radosevich ${ }^{3}$ \\ ${ }^{1}$ Department of Forestry, Wildlife and Fisheries, University of Tennessee, Knoxville, USA \\ ${ }^{2}$ USDA-Forest Service, FIA, Knoxville, USA \\ ${ }^{3}$ Department of Biosystems Engineering and Soil Science, University of Tennessee, Knoxville, USA \\ Email:breicher@vols.utk.edu, jeanphil@utk.edu, coswalt@fs.fed.us, jafranklin@utk.edu, mrad@utk.edu
}

Received 29 December 2014; accepted 12 January 2015; published 23 January 2015

Copyright (C) 2015 by authors and Scientific Research Publishing Inc.

This work is licensed under the Creative Commons Attribution International License (CC BY).

http://creativecommons.org/licenses/by/4.0/

(c) (i) Open Access

\section{Abstract}

As the process of urbanization advances across the country, so does the importance of urban forests, which include both trees and the soils in which they grow. Soil microbial biomass, which plays a critical role in nutrient transformation in urban ecosystems, is affected by factors such as soil type and the availability of water, carbon, and nitrogen. The aim of this study was to characterize residual forest patches and open fields in residential areas in the City of Knoxville. A field study was conducted to investigate tree species diversity and determine spatial and temporal soil characteristics along an urban-to-rural gradient. Tree diversity did not differ significantly for residential urban and rural plots in Knoxville, Tennessee. Biologically, there was no indication that soils were affected by tree diversity, in terms of soil microbial biomass $\mathrm{C} / \mathrm{N}$ along an urban-to-rural gradient in Knoxville residential plots. Rural soils did differ physically from urban soils, cation exchange capacity (CEC) and soil moisture content (GSM). Similarly, physical soil properties such as bulk density, both urban and rural sites were negatively correlated with tree diversity. Results indicate that although the urban-rural gradient is subject to urban environmental stressors, the urban ecosystem is resilient in maintaining the ecosystem functions of more natural systems.

\section{Keywords}

Forest Soils, Soil Function, Soil Chemistry, Urban Trees, Urban Soils 


\section{Introduction}

Various non-FIA inventories such as city tree inventories have been periodically conducted almost exclusively within city limits of urban areas, but inventories on residential areas (i.e. backyard trees, small woodlots in the middle of developments, or patches of residual forest lands) are limited as is the impact these "non-forested areas" as defined by FIA standards have on cycling of elements, tree diversity and soil microbial biomass. Dwyer et al. (2000) reported, from the first national assessment of urban forests within the conterminous United States, urban areas (metropolitan counties) cover $24.5 \%$ of the land and contain 74.4 billion trees. Urban areas have doubled in size over the past 20 - 25 years; unfortunately urban tree cover declined across the United States at an annual rate of about 4 million trees annually from 2001-2009 (Nowak \& Greenfield, 2012). Tree cover across the United States within urban areas is dynamic due to natural and anthropogenic causes. Natural causes include regeneration, tree growth and mortality, and the presence of insects and diseases (Nowak \& Greenfield, 2012). Anthropogenic causes include urban sprawl from residential and commercial developments, particulate matter and reactive nitrogen from automobile exhaust, industrial pollution, and over-use of pesticides and fertilizers (Nowak et al., 2006a; Nowak, 2002). Historically, forests have been the largest source of land for development purposes of the major land uses (Alig \& Plantinga, 2004). Nowak et al. (2009) reported on the first statewide inventory and forest health monitoring to quantify and describe the ecosystem services and values of the State of Tennessee urban forests. Tennessee’s urban forests have an estimated structural value of \$79 billion, provide an annual energy saving to residents of \$66 million, remove \$204 million worth of pollution from the air annually and store 16.9 million tons of carbon valued at \$350 million. Tennessee’s urban areas have an estimated 284.1 million trees as compared 8 billion trees in forests outside urban areas across the State.

Some important functions of urban forests such as carbon storage and nutrient transformation take place in urban soils. Several definitions of soils associated in urban areas have been proposed in the literature (Bockheim, 1974; Evans et al., 2000; Pouyat \& Effland, 1999); recently Lehmann and Stahr, 2007 broadly define urban soils as physically disturbed (e.g. old industrial sites and landfill) and undistributed, and altered by urban environmental changes (e.g. temperature or moisture regimes). Soils in urban areas are highly disturbed and heterogeneous, with minimal systematic pattern in their characteristics (Pouyat et al., 2010). Soils in urban areas are exposed to vehicle and factory emissions, oil, gas, fertilizer, pesticides, and other pollutants that run off from urban areas. Additionally, construction activities, compaction, and surface sealing affect soil properties, often resulting in reduced critical function. Most urban soil studies have focused on soils along streets and in highly compacted areas (Patterson et al., 1980; Short et al., 1986a; Jim, 1998), and the results indicated that urban soil was drastically disturbed and low in fertility. However, the biological, chemical and physical response of soils to urban land use across the entire landscape is complex and varies, such that soils in urban areas have been identified that are largely undisturbed or highly fertile (Hope et al., 2005; Pouyat et al., 2007).

Soil quality is the capacity of a soil to function within "ecosystem boundaries" to sustain biological productivity, maintain environmental quality, and promote plant and animal health. Soil quality assessment provides a basic means to evaluate the sustainability of agricultural and land management systems. Our ability to assess soil quality and identify key soil properties that serve as indicators is complicated by the multiplicity of physical, chemical, and biological factors that control biochemical processes. Practical assessment of quality requires consideration of all these functions (Doran et al., 1994). Soils have various levels of quality that are defined by stable or inherent features related to soil-forming factors and dynamic changes induced by soil management. Detecting changes in the dynamic component of soil quality is essential to evaluating the performance and sustainability of soil management systems (Doran et al., 1994). A set of indicators of soil quality for urban soils has not been previously defined, largely due to the difficulty in defining and identifying what soil quality represents and how it can be measured (Doran et al., 1994).

To understand the sustainability of land management systems, an emphasis on soil quality assessment is crucial (Aon et al., 2001). The assessment of soil quality is beneficial to determining the sustainability of land management systems (Aon et al., 2001). Identifying early signals of ecosystems stress may provide advance warning about soil degradation as compared to other classical and slowly changing soil properties, such as organic matter (Dick, 1994). Land use can influence the ability of soil to process nutrients, the soil's biochemical processes, and soil quality. Possible indicators of soil quality and land management changes include soil texture, soil bulk density, water holding capacity, soil temperature, microbial biomass, organic $\mathrm{C}$ and $\mathrm{N}$, soil respiration, soil enzyme activity, and soil microbial populations. 
Soil microbial biomass is critical to the maintenance of good soil quality because microorganisms are involved in important soil functions such as carbon and nitrogen cycling, soil tilth (tillage) and structure, and organic matter transformation (Singh et al., 1989; Ibekwe et al., 2002). Soils that suffer physical, chemical, and biological degradation such as erosion and compaction, acidification, nutrient depletion, industrial pollution, over-use of pesticides and fertilizers, and organic matter depletion, also suffer losses of biodiversity (Girvan et al., 2003). Disturbances affect the aboveground biota (e.g. plant community composition, density and cover), soil chemical characteristics (e.g. pH, organic matter quantity and quality), and thus belowground soil biota (Certini, 2005; Hart et al., 1994; Neary et al., 1999). Soil microbes regulate the cycling of $\mathrm{C}$ and $\mathrm{N}$ in soils, function in soil formation, groundwater quality maintenance, and contaminant degradation (Zak et al., 2003; Fierer et al., 2003). Transformation of non-urban lands to urban land use has the potential to modify soil carbon pools and fluxes (Pouyat et al., 2002). Microbial carbon to total organic carbon (MBC/TOC), and microbial carbon to nitrogen (MBC/MBN) are reliable indicators for organic matter quality or community composition (Scharenbroch et al., 2005).

Soils in urban areas are created through physical disturbance, directly altering the biogeochemical transformation of C and N through the synergistic effect of key soil and organism processes (McDonnell et al., 1997; Pickett et al., 2001). Mixing perturbs the partitioning of coarse material, the soil structure and texture and alters the depth distribution of C and N (Craul, 1999). Additionally pore volume and macro-pores are affected in the top soil, while the subsoil layers are usually compacted, but depending on the depth of disturbance and machinery used, the subsoil may be loose (Baumgartl, 1998). The aim of this study was to characterize residual forest patches and open fields in residential areas in the City of Knoxville. Here we conducted a field study to investigate tree species diversity and quantitatively determine soil chemical, physical and biological characteristics along an urban-rural gradient within the City of Knoxville, TN. We tested whether tree diversity affected the quantitative change in soil chemical, biological and physical properties among sampled plots by season (fall, summer, winter and spring) and location (urban versus rural).

\section{Methods}

\subsection{Site Description}

The city of Knoxville is situated in the Great Appalachian (Tennessee) Valley in the Upper Tennessee Basin and is the third largest metropolitan city in the State of Tennessee (Figure 1). Historically, during the early 1800s the area that is now Knoxville, TN was inhabited by the Cherokee Indians (Deaderick, 1976). North Carolina legislature passed the "land grab act" in 1783 which resulted in the purchase and development of (640 acres) Knoxville area lands by John Yates (Deaderick, 1976). Agricultural land use in Knox Co. changed since 1900 from predominantly crop production to mainly feed for cattle (Knoxville and Knox County Planning Commission, 1988). In 1933, the Tennessee Valley Authority (TVA) was established in Knoxville to solve problems caused by city development via soil conservation, reforestation, and improved agricultural practices (Knoxville and Knox County Planning Commission, 1988). The city of Knoxville has a mean housing density of 1.07 residences per acre and median of 0.55 houses per acre (Cho et al., 2006). The city has a total area of $269.38 \mathrm{~km}^{2}$ (255.2 $\mathrm{km}^{2}$-land and $14.6 \mathrm{~km}^{2}$ - water). The climate is temperate with no distinct wet and dry season, with average temperature in summer $24.5^{\circ}$ and winter $4.1^{\circ}$ and annual precipitation 119.74 centimeters (Hampson et al., 2000; Hartgrove, 2004). The Natural Resource Conservation Service classified general soil types in Knox Co. as inceptisols and ultisols. These soils formed under forest vegetation typically have light color, and range in depth from shallow to very deep with underlying bedrock consisting of limestone, dolomite, shale, siltstone, and sandstone (Hartgrove, 2004).

\subsection{Identification of Urban and Rural Plots}

To identify potential urban and rural plots in Knox Co. we used ArcGIS to place a boundary box over the state of Tennessee. At both the northeast and southwest positions within the boundary box two $x, y$ coordinates were established and the difference between $x_{1}$ and $x_{2} / y_{1}$ and $y_{2}$ was calculated with the equation Rand ()*differences $+x_{2}$ in Excel. Initially, approximately 78,000 0.40-hectar (tenth-acre) potential sampling points were randomly generated in Excel and exported to ArcGIS program (ArcMap10.0) to create a shape file. The city of Knoxville was isolated and demographic information such as race, age (median age), average family size, property owners 


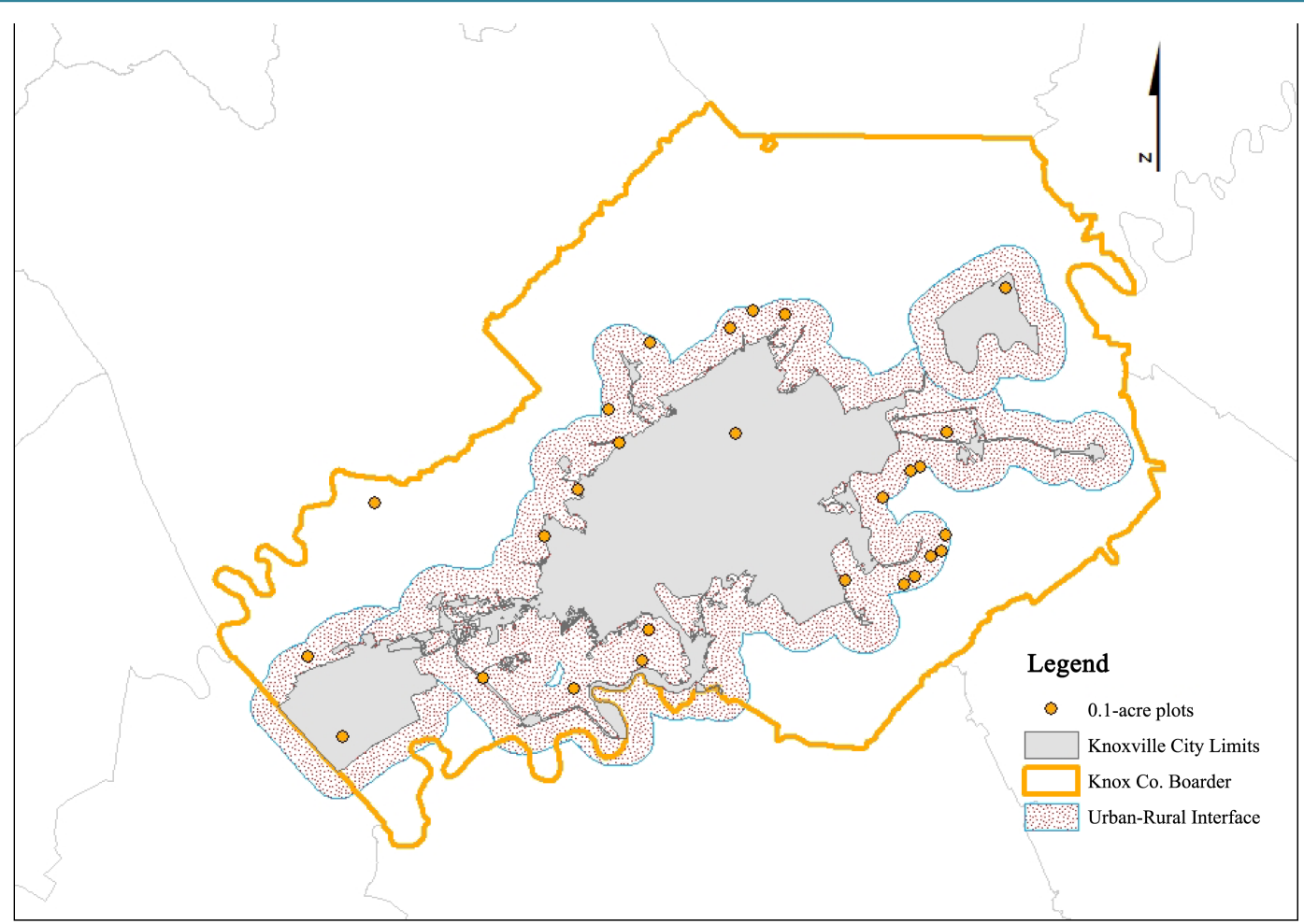

Figure 1. Map of urban forest study site in Knox Co., Tennessee.

versus renters, housing units occupied, families, farmland and average lot size was generated for each 0.40 hectar (tenth-acre) potential sampling point as well as urban and rural-residential areas within the established 1.609 kilometer (1 mile) buffer zone for the city. This assessment defined urban boundaries using the 2000 US Census Bureau data (US Department of Commerce, 2010), to be consistent with the USDA Forest Service, Forest Health and Monitoring

(FMH) programs 2001 assessment of urban forest conditions. Following the FMH programs definition of urbanized areas 2918 tenth-acre potential sampling points landed within the urban boundary. There was total of 423 0.40-hectar (tenth-acre) potential sampling points for the City of Knoxville selected based on areas with population densities $\geq 50,000$ for Knox Co. Tennessee (Nowak et al., 2011). The shape file (ArcMap 10.1) was exported to a KML file to visually accept or reject potential sampling points in Google Earth using imagery data from 2011 for the city of Knoxville. Guidelines for acceptance of potential sampling points included areas $\geq$ 0.40 hectare forested or open field (non-agricultural) and residential properties only; points that landed in commercial lands, government lands, on tops of buildings, in the water, on impervious cover (streets and parking lots), or where the edge of each 0.4 hectare plot measured to $\geq 30.48$ meters from any structure, were rejected. Accepted potential points numbered 180, of which twenty-six were selected for sampling based on acceptance by residential land owners. The 26 plots consisted of 10-urban residential and 16-rural residential plots. Rural plots were within $1.609 \mathrm{~km}$ of the Knoxville city-limits. This plot size was chosen in order to capture sufficient tree data but to avoid multiple ownerships and has been used in other city wide inventories of urban forest (Riemann, 2003).

Due to the topographic differences that affect soil composition and water flow, our study area was divided into four quadrants (Figure 2). The northeast (8 plots) is mostly ridge tops and shoulders with a general soil material of the Corryton-Townley complex, having 5 to 12 percent slopes, with most areas cleared and used for hay, pasture, or cropland. The southeast (5 plots) is mostly shoulders, side slopes, and back-slopes with a general soil material consisting of the Loyston-Talbott-Rock outcrop complex, having 15 - 50 percent slopes, mainly in woodland and cleared areas that are used as pasture or remain idle. The southwest (6 plots) is mostly shoulders, foot-slopes, toe-slopes, and side slopes with a general soil material consisting of Coghill-Corryton complex, having 5 - 25 percent slopes, and mainly woodland consisting of mixed hardwoods and areas cleared for resi- 


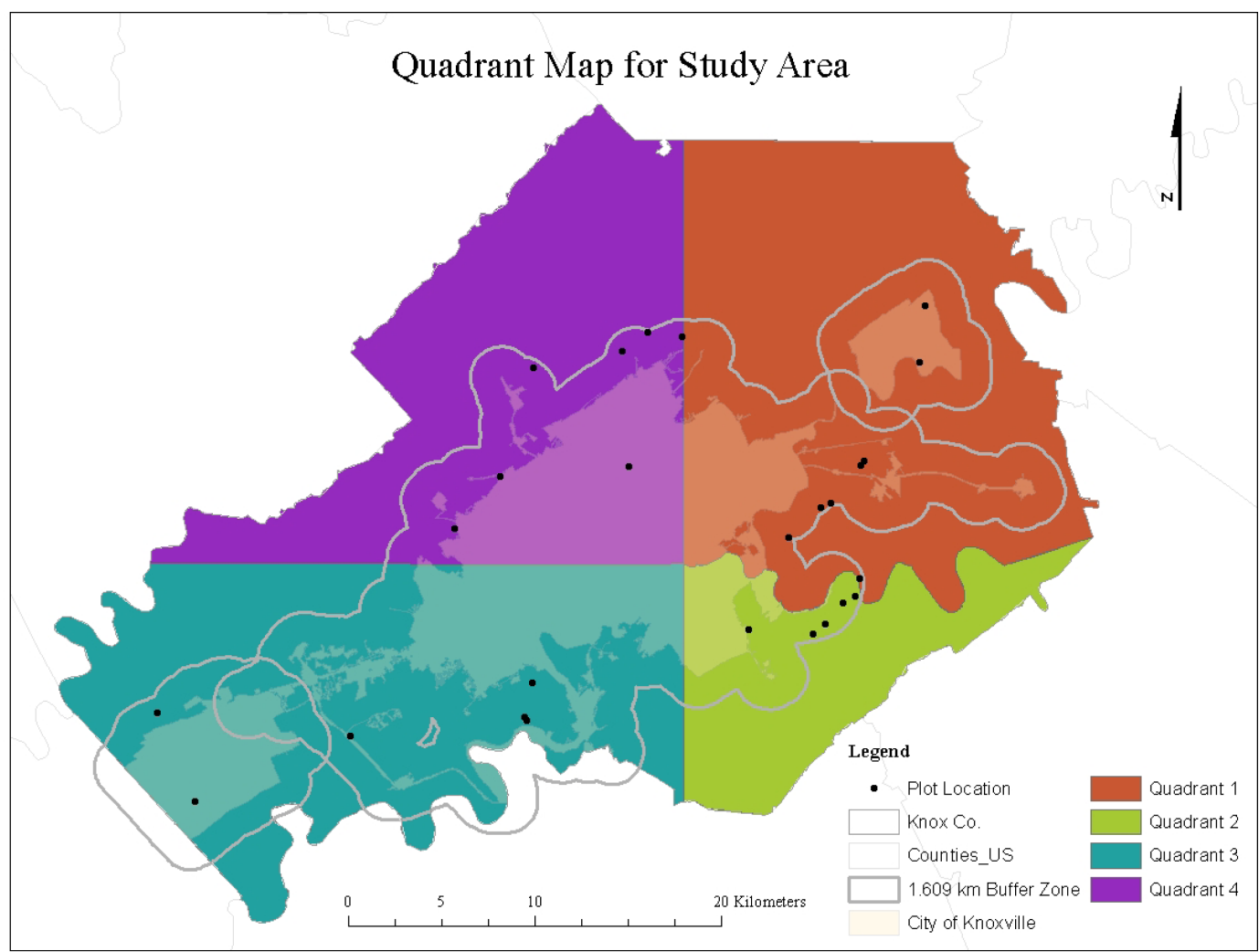

Figure 2. Twenty-six-0.4 ha residents plot locations in the four quadrants within the city of Knoxville and a 1609 km buffer zone for Knox Co., Tennessee.

dential or commercial developments. The northwest (7 plots) is mostly on shoulders, side slopes, and backslopes with a general soil material consisted of the Apison-Montevallo complex, having 35 - 75 percent slopes, with most areas in woodland onsisting mainly of mixed hardwoods. The entire study area is generally well drained.

\subsection{Tree Inventory and Soil Sampling}

Within urban and rural residential plots tree species and diameter were inventoried for woody plants measuring > $2.54 \mathrm{~cm}$ diameter at breast height. Soils were sampled during June 2012, October 2012, January 2013 and April 2013. In each plot six $2 \mathrm{~cm}$ diameter by $30.4 \mathrm{~cm}$ deep soil cores were randomly collected, combined and mixed in the field, placed in 25- $\mu \mathrm{m}$ thick polyethylene storage bags, placed in coolers with ice, and taken back to the lab where they were processed for analysis. Subsamples from the heterogeneous mixture were used for total elemental, soil microbial biomass $\mathrm{C} \& \mathrm{~N}$, total organic carbon (TOC), pH, CEC, bulk density and GSM analysis. To measure relative dominance of species in our 26-0.04 ha plots we utilized the importance value (IV) calculation (Curtis \& McIntosh, 1951; Kent \& Coker, 1992). Importance values rank species within a site based upon three criteria 1) relative frequency (species occurrence), 2) relative density (total number of individual species) and 3) relative dominance (total amount of forest area occupied) (Curtis \& McIntosh, 1951; Kent \& Coker, 1992). Plots with multiple species within a genus were grouped and importance value calculations were averaged. The geographic center $(-83.942222,35.972778)$ for the city of Knoxville was used to calculate the distance from city-center for each plot. This distance metric was used to place each plot on an urban-to-rural gradient.

\subsection{Soil Analysis}

All soil samples ( $0.2 \mathrm{~g})$ were air dried for 2 days then passed through a $250 \mu \mathrm{m}$ (60-mesh) sieve. Microwave oven digestion by Nadkarni (1984), with modifications; was used for elemental analysis. Elemental analysis of 
the digested soil samples was analyzed by inductively coupled atomic emission spectrometry (ICP). Exchangeable As, Ba, Ca, Cd, Co, Cr, Cu, Fe, K, Mg, Mn, Mo, Na, Ni, P, Pb, S, Se, Sr, Ti, and Zn were determined by extraction with $1 \mathrm{~N}$ ammonium acetate $\left(1 \mathrm{NH}_{4} \mathrm{OAc}, \mathrm{pH} 7.0\right)$. The $\mathrm{pH}$ of the $1 \mathrm{NH}_{4} \mathrm{OAc}$ was adjusted by adding concentrated ammonium hydroxide. Exchangeable $\mathrm{Al}$, As, $\mathrm{Ba}, \mathrm{Ca}, \mathrm{Cd}, \mathrm{Co}, \mathrm{Cr}, \mathrm{Cu}, \mathrm{Fe}, \mathrm{K}, \mathrm{Mg}, \mathrm{Mn}, \mathrm{Mo}, \mathrm{Na}, \mathrm{Ni}$, $\mathrm{P}, \mathrm{Pb}, \mathrm{S}$, Se, Sr, Ti, and $\mathrm{Zn}$ were analyzed by ICP. The sodium saturation method (pH 7.0) was used to determine CEC (Chapman, 1965). Soil bulk density $D_{b}=m_{s} / V_{t}$ is the ratio of the mass of oven-dried solids $\left(m_{s}\right)$ to the bulk volume $\left(V_{t}\right)$ of the soil, which include the volume of the solids and the pore space between the soil particles (Blake and Hartge, 1986). Soil bulk density was calculated asoven dry weight $\left(m_{s}\right)$ divided by the volume of the soil core $\left(V_{t}\right)=\mathrm{g} \cdot \mathrm{cm}^{-3}$.

Gravimetric soil moisture $(\Theta g)$ was calculated as the difference between soil fresh weight $\left(m_{w}\right)$ and oven dry weight $\left(m_{s}\right)$ using the following equation: $\Theta g=\left(m_{w}-m_{s}\right) / m_{s}$.

\subsection{Soil Microbial Biomass Analysis}

The simultaneous chloroform fumigation extraction (sCFE) "slurry" method was adapted from Fierer (2003) for microbial biomass carbon (MBC) and microbial biomass nitrogen (MBN). To analyze total carbon and nitrogen a TOC-VCPH SHIMADZU (detection limit $0.1 \mathrm{ppm}$ ) was used. Microbial C biomass was determined using the following equation:

$$
\mathrm{MBC}=\mathrm{EC} / k \mathrm{EC}
$$

where the chloroform-labile pool (EC) is the difference between $\mathrm{C}$ in the fumigated and non-fumigated extracts, and $k E C$ is soil-specific and estimated as 0.45 (Beck et al., 1997). Microbial N biomass was determined using the following equation:

$$
\mathrm{MBN}=\mathrm{EN} / k \mathrm{EN}
$$

where the chloroform-liable $\mathrm{N}$ pool is the difference between $\mathrm{N}$ in the fumigated and non-fumigated extracts, and $k E N$ is soil-specific and estimated as 0.54 (Brookes et al., 1985). MBC and MBN were expressed as $\mu g \mathrm{~N}$ $\mathrm{g}^{-1}$. Soil carbon to nitrogen, microbial biomass carbon to nitrogen and microbial carbon to organic carbon ratios were calculated. To analyze total organic carbon the TOC by acidification/sparging method was used. To analyze total nitrogen a TNM-1 SHIMADZU unit was used (detection limit $0.1 \mathrm{ppm}$ ).

\subsection{Data Analysis}

Tree species diversity in plots was calculated by the Shannon (1949) diversity index as:

$$
H^{\prime}=\sum_{i=1}^{s}\left(P_{i} \times \ln P_{i}\right)
$$

where, $s=$ number of species and, $p_{i}$ is the fraction of the entire population made up of species $i$. Tree less plots were included in calculation of tree diversity. The Pearson correlation coefficient parametric test was used to correlate MBC, MBN, TOC, tree species diversity, tree diameter, CEC, $\mathrm{pH}$, bulk density, soil moisture, average $\mathrm{Al}$, As, Ba, Ca, Cd, Co, Cr, Co, Fe, K, Mg, Mn, Mo, Na, Ni, P, Pb, S, Sr, Ti and Zn. Principle component analyses (PCA) was used to reduce the variable dimensions and provide information to identify the variance with in the data set. Linear regression stepwise method was used to retain predictors in the best regression model for distance using the variables: MBC, MBN, TOC, tree species diversity, CEC, $\mathrm{pH}$, bulk density, soil moisture, average Al, As, Ba, Ca, Cd, Co, Cr, Co, Fe, K, Mg, Mn, Mo, Na, Ni, P, Pb, S, Sr, Ti and Zn. All analyses were performed with SPSS 19 (IBM Corp., Armonk, NY USA) and SAS 9.3 (SAS Inc., Cary, NC USA).

\section{Results}

The total number of trees that were inventoried along the urban-to-rural transect in Knoxville was 958, with forty-nine woody plant species identified (Table 1). The most abundant tree species within all plots sampled were Pinus virginiana, Acer rubrum, Juniperus virginiana, Ulmus Americana, Acer saccharum, and Liriodendron tulipifera L. The five most abundant species based on IV calculations within each quadrant were: Carya spp., Celtis spp., Juniperus spp., Quercus spp., and Ulmus spp. (Quadrant 1); Carya spp., Celtis spp., Juniperus spp., Pi- 
Table 1. Species by occurrence, relative abundance, and relative dominance along an urban-to-rural gradient in Knoxville, TN.

\begin{tabular}{|c|c|c|c|}
\hline Species & Species Occurrence & Relative Abundance (\%) & Relative Density (\%) \\
\hline Acer negundo & 1 & 0.10 & 0.00 \\
\hline Acer rubrum & 85 & 8.87 & 2.42 \\
\hline Acer saccharum & 54 & 5.64 & 3.62 \\
\hline Aesculus flava & 8 & 0.84 & 1.52 \\
\hline Amelanchier arborea & 2 & 0.21 & 0.11 \\
\hline Carya cordiformis & 2 & 0.21 & 0.08 \\
\hline Carya glabra & 4 & 0.42 & 1.46 \\
\hline Carya ovata & 41 & 4.28 & 6.02 \\
\hline Carya sp. & 10 & 1.04 & 1.96 \\
\hline Carya tomentosa & 39 & 4.07 & 5.49 \\
\hline Celtis laevigata & 1 & 0.10 & 0.02 \\
\hline Celtis occidentalis & 36 & 3.76 & 0.55 \\
\hline Cercis canadensis & 30 & 3.13 & 0.41 \\
\hline Cornus florida & 36 & 3.76 & 0.85 \\
\hline Fagus grandiflora & 40 & 4.18 & 0.87 \\
\hline Fraxinus americana & 1 & 0.10 & 1.78 \\
\hline Fraxinus pennsylvanica & 12 & 1.25 & 1.51 \\
\hline Hamamelis virginiana & 9 & 0.94 & 0.09 \\
\hline Juglans nigra & 8 & 0.84 & 0.81 \\
\hline Juniperus virginiana & 96 & 10.02 & 4.58 \\
\hline Ligustrum sinense Lour. & 27 & 2.82 & 0.23 \\
\hline Lindera benzoin & 1 & 0.10 & 0.00 \\
\hline Liquidambar styraciflua & 26 & 2.71 & 1.51 \\
\hline Liriodendron tulipifera & 37 & 3.86 & 9.83 \\
\hline Magnolia acuminata & 1 & 0.10 & 0.00 \\
\hline Morus rubra & 6 & 0.63 & 0.05 \\
\hline Nyssa sylvatica & 4 & 0.42 & 0.71 \\
\hline Oxydendrum arboreum & 21 & 2.19 & 2.37 \\
\hline Pinus echinata & 24 & 2.51 & 3.29 \\
\hline Pinus virginiana & 108 & 11.27 & 17.91 \\
\hline Platanus occidentalis & 9 & 0.94 & 1.75 \\
\hline Prunus serotina & 22 & 2.30 & 2.93 \\
\hline Pyrus calleryana & 2 & 0.21 & 0.11 \\
\hline Quercus alba & 31 & 3.24 & 15.34 \\
\hline Quercus falcata & 9 & 0.94 & 1.95 \\
\hline
\end{tabular}




\begin{tabular}{cccc} 
Continued & & & \\
\hline Quercus lyrata & 8 & 0.84 & 0.37 \\
Quercus montana & 7 & 0.73 & 0.37 \\
Quercus muehlenbergii & 1 & 0.10 & 0.01 \\
Quercus phellos & 1 & 0.10 & 2.71 \\
Quercus rubra & 8 & 0.84 & 0.49 \\
Quercus stellata & 6 & 0.63 & 0.06 \\
Quercus velutina & 3 & 0.31 & 0.91 \\
Sassafras albidum & 8 & 0.84 & 0.06 \\
Tilia americana & 1 & 0.10 & 0.28 \\
Tsuga canadensis & 1 & 0.10 & 0.21 \\
Ulmus alata & 10 & 1.04 & 1.56 \\
Ulmus americana & 55 & 5.74 & 0.02 \\
Ulmus rubra & 2 & 0.21 & 0.02 \\
Unknown & 3 & 0.31 & 0.00
\end{tabular}

nus spp., and Ulmus spp. (Quadrant 2); Acer spp., Carya spp., Fagus spp., Liriodendron spp., and Quercus spp. (Quadrant 3); Acer rubrum, Liqustrum spp., Pinus spp., Prunus spp., and Quercus spp. (Quadrant 4). Shannon’s diversity index for $76 \%$ (20) of sampled plots in rural areas mean $H^{\prime}=1.30 \pm 1.0$ as compared to urban areas mean $H^{\prime}=1.51 \pm 0.73$. Quadrant mean Shannon's diversity indices were $H^{\prime}=1.13 \pm 1.24(\mathrm{Q} 1), H^{\prime}=1.82 \pm 0.37$ (Q2), $H^{\prime}=1.85 \pm 0.53(\mathrm{Q} 3)$, and $H^{\prime}=0.94 \pm 0.84(\mathrm{Q} 4)$.

Soil MBC mean in rural plots was $109.75 \pm 60.74 \mu \cdot \mathrm{g}^{-1}$ (summer) $187.16 \pm 417.19 \mu \cdot \mathrm{g}^{-1}$ (fall), $51.15 \pm 41.77$ $\mu \cdot \mathrm{g}^{-1}$ (winter) and $110.31 \pm 74.03 \mu \cdot \mathrm{g}^{-1}$ (spring), whereas urban MBC mean was $86.49 \pm 90.65 \mu \cdot \mathrm{g}^{-1}$ (summer), $96.28 \pm 139.39 \mu \cdot \mathrm{g}^{-1}$ (fall), $45.4 \pm 53.67 \mu \cdot \mathrm{g}^{-1}$ (winter) and $68.67 \pm 40.7 \mu \cdot \mathrm{g}^{-1}$ (spring). Rural soil MBN mean was $10.17 \pm 4.64 \mu \cdot \mathrm{g}^{-1}$ (summer), $9.5 \pm 8.61 \mu \cdot \mathrm{g}^{-1}$ (fall), $18.41 \pm 48.22 \mu \cdot \mathrm{g}^{-1}$ (winter) and $10.89 \pm 12.21 \mu \cdot \mathrm{g}^{-1}$ (spring), whereas urban MBN mean was $7.03 \pm 6.73 \mu \cdot \mathrm{g}^{-1}$ (summer), $13.73 \pm 32.67 \mu \cdot \mathrm{g}^{-1}$ (fall), $5.46 \pm 3.75$ $\mu \cdot \mathrm{g}^{-1}$ (winter) and $5.0 \pm 7.41 \mu \cdot \mathrm{g}^{-1}$ (spring) (Table 2).

In soils we identified twenty-three major and trace elements. Based on Pearson's correlation coefficient bulk density in both urban ( $\mathrm{r}=-0.555, p<0.001)$ and rural $(\mathrm{r}=-0.692, p<0.001)$ locations were negatively correlated to tree diversity (Table 3). However, GSM ( $\mathrm{r}=0.367, p<0.01)$ and CEC ( $\mathrm{r}=0.347, p<0.01)$ in rural plots was positively correlated to tree diversity (data not shown). Additionally, in rural locations, GSM, pH, three macro-nutrients (Ca, Mg and S) and Pb were significantly correlated $(p<0.05)$ to MBC and MBN. Total C and N, CEC, bulk density, TOC, GSM, three macro nutrients (Ca, Mg, and S), Cr and Ti were significantly positively correlated $(p<0.05)$ (Table 3$)$. There was no significant correlation $(\mathrm{r}=0.101, \mathrm{r}=-0.001, p=0.539, p$ $=0.994$ ) found between tree diversity and urban MBC or urban MBN, respectively by season, location (urban/rural) or season $*$ location (uban/rural). Since tree diversity was not a significant covariate either as a simple covariate interaction with season and location (fixed), we removed the covariate and reran the MANOVA. Based on our repeated measures MANOVA there was no significant effect of season and no significant interaction with location (urban or rural) with MBC and MBN. We next evaluated the differences in soil physical properties (pH and GSM) between locations and seasons and found a significant difference in means by season $(p<0.001)$, but there is no significant interaction of season and location $(p=0.257)$. Soil $\mathrm{pH}$ values were between 3.17 and 8.28 in urban and 3.59 and 7.72 in rural plots, with $\mathrm{pH}$ significantly correlated $(p<0.001)$ to rural MBC. Soil CEC tended to be higher in rural $\left(4.3 \mathrm{cmol} \cdot \mathrm{g}^{-1}\right)$ than urban $\left(3.7 \mathrm{cmol} \cdot \mathrm{g}^{-1}\right)$ plots, with CEC significantly correlated $(p<0.05)$, in urban locations (Table 3). 
Table 2. Soil microbial biomass Carbon $\left(\mu \mathrm{C} \mathrm{g}^{-1}\right)$ and Nitrogen $\left(\mu \mathrm{N} \mathrm{g}^{-1}\right)$ by location (urban/rural) and season (summer, fall, winter, spring) for Knoxville, TN.

\begin{tabular}{cccccccccccc}
\hline \multicolumn{7}{c}{ Soil Microbial Biomass Carbon $\left(\mu \cdot g^{-1}\right)$} & & & \\
\hline Urban & Min. & Max & Mean & SE & STDV & Rural & Min. & Max & Mean & SE & STDV \\
\hline Summer & 13.44 & 283.19 & 86.49 & 30.22 & 90.65 & & 11.28 & 198.42 & 109.75 & 15.68 & 60.74 \\
Fall & 0 & 474.8 & 96.28 & 44.08 & 139.39 & & 0 & 1740.4 & 187.16 & 104.3 & 417.19 \\
Winter & 7.76 & 183.24 & 45.4 & 16.97 & 53.67 & & 4.2 & 174.24 & 51.15 & 10.44 & 41.77 \\
Spring & 15.91 & 145.04 & 68.67 & 12.87 & 40.7 & & 29.62 & 324.27 & 110.31 & 18.51 & 74.03 \\
\hline & & & & Soil Microbial Biomass Nitrogen $\left(\mu \cdot g^{-1}\right)$ & & & & \\
Urban & Min. & Max & Mean & SE & STDV & Rural & Min. & Max & Mean & SE & STDV \\
\hline Summer & 0 & 18.3 & 7.03 & 2.24 & 6.73 & & 3.29 & 20.57 & 10.17 & 1.2 & 4.64 \\
Fall & 0 & 102.22 & 13.73 & 10.33 & 32.67 & & 0 & 30.87 & 9.5 & 2.15 & 8.61 \\
Winter & 1.8 & 12.05 & 5.46 & 1.18 & 3.75 & & 0.73 & 198.36 & 18.41 & 12.08 & 48.32 \\
Spring & 0 & 18.36 & 5 & 2.34 & 7.41 & & 0 & 38.43 & 10.89 & 3.05 & 12.21 \\
\hline
\end{tabular}

Soils were samples collected (summer) June 2012, (fall) October 2012, (winter) January 2013 and (spring) April 2013.

Pearson's correlation between population density, distance ( $\mathrm{km})$, ICP analytes, biological and physical properties for summer indicated negative correlations for distance, $\mathrm{Co}, \mathrm{Fe}, \mathrm{Na}, \mathrm{Ni}$, and $\mathrm{P}$ at $(p<0.05)$. Additionally, $\mathrm{pH}$ was positively correlated with population density at $(p<0.001)$ and GSM had a negative correlation at $(p<$ 0.001) (data not shown). Distance and GSM for fall, winter and spring were negatively correlated with population density at $(p<0.05)$ (data not shown). Principal component analysis (PCA) produced a total of twenty-nine components. These are the ten components with the heights extracted eigenvalues which account for ninety-nine percent of the variance among the 29 variables. From the ten components only components one and two were retained for the correlation matrix with distance for geographic city center and chemical, biological, and physical properties. Component one accounted for 82.422 percent of the total variance were as component two accounted for 11.064 percent of the total variance among the variables. The combined components (1 and 2) account for $93.486 \%$ of the variance in the total set of variables in the PCA. That is, the 29 variables can be reduced to two dimensions (components) that account for as much variance as the 29 variables. Pearson's Correlations between distance and component scores, where generic first component is not correlated with distance. The second component has a negative correlation with distance at the $p<0.001$. So as distance from the city center increases the component 1 scores decreases or vice-versa.

Linear regression stepwise backward elimination method was used to retain predictors in the best regression model for distance. The last model retained, with the predictors Ba ppm and Sr ppm, explains about 7\% (0.067) of the total variation in distance to city center. The model retained two predicative constants with at least one significant predictor of distance: $\mathrm{F}=4.62 ; \mathrm{df}=2.99 ; p=0.012$.

Regression equation for the final model:

Predicted value of distance $=12.009+0.390 \pm 0.005 \mathrm{Ba}$ ppm $-0.282 \pm 0.037 \mathrm{Sr}$ ppm.

Standardized Betas indicate that Ba ppm (0.390) is a stronger predictor than $\mathrm{Sr}$ ppm $(-0.282)$. t-tests on the regression coefficients $(\mathrm{B})$ show that both are significant predictors: Ho: $\mathrm{B}=0$ Ba ppm: $\mathrm{t}=3.028$; $\mathrm{df}=1.99 ; p=$ 0.003 and Sr ppm: $\mathrm{t}=-2.195 ; \mathrm{df}=1.99 ; p=0.031$ for both, Ho is rejected at alpha $=0.05$.

\section{Discussion}

Urban and rural areas have distinct differences in plant species composition and soil characteristics (Porter et al., 2001). One way to assess forest community structure in urban forests is to calculate IVs for each species within designated urban forest plots or whole communities in urban areas. Nowak et al. (2006a) analyzed forest structure (i.e. tree species composition, species diversity, number of trees, etc.), forest function (i.e. environmental and ecosystem services) and forest value (i.e. economic worth) within the Washington DC area. To identify 
Table 3. ICP analysis along an urban-to-rural gradient and Pearson's correlation between MBC, MBN, ICP analytes, pH, CEC and TOC.

\begin{tabular}{|c|c|c|c|c|c|c|c|c|c|c|c|}
\hline Urban & Min. & Max. & Mean & Corr. Coeff. & Sig. ${ }^{\text {(2tailed) }}$ & Rural & Min. & Max. & Mean & Corr. Coeff. & Sig. ${ }^{\text {(2tailed) }}$ \\
\hline \multicolumn{12}{|c|}{ Topsoil 25.4" } \\
\hline $\mathrm{pH}$ & 3 & 8 & 5.7 & 0.241 & 0.156 & & 4 & 8 & 5.9 & $0.216^{*}$ & 0.046 \\
\hline CEC & 2.8 & 5.2 & 3.7 & $0.642^{* *}$ & $<0.001$ & & 1.9 & 6 & 4.3 & $0.298^{*}$ & 0.026 \\
\hline TOC & 5 & 66 & 11.9 & $0.927^{* *}$ & $<0.001$ & & 1 & 110 & 12.0 & $0.598^{* *}$ & $<0.001$ \\
\hline $\mathrm{MBC}$ & 2 & 475 & 78.5 & $0.773^{* *}$ & $<0.001$ & & 0 & 324 & 92.4 & $0.789^{* *}$ & $<0.001$ \\
\hline MBN & 0 & 18 & 6.7 & $0.773^{* *}$ & $<0.001$ & & 0 & 38 & 10.0 & $0.789^{* *}$ & $<0.001$ \\
\hline \multicolumn{12}{|l|}{ Analytes } \\
\hline $\mathrm{Al} \mathrm{mg} \mathrm{kg}{ }^{-1}$ & 9260 & 86,400 & 37511 & 0.009 & 0.959 & & 12,780 & 117,600 & 48071 & 0.165 & 0.212 \\
\hline As $\mathrm{mg} \mathrm{kg}^{-1}$ & 1 & 32 & 11.5 & $0.460^{* *}$ & 0.007 & & 0 & 41 & 9.4 & -0.034 & 0.799 \\
\hline Ba mg kg ${ }^{-1}$ & 62 & 790 & 274 & $0.386^{*}$ & 0.026 & & 126 & 656 & 285 & -0.242 & 0.065 \\
\hline Ca mg kg ${ }^{-1}$ & 500 & 14,300 & 2585 & $0.420^{*}$ & 0.015 & & 935 & 24,795 & 4450 & $0.510^{* *}$ & $<0.001$ \\
\hline $\mathrm{Cd} \mathrm{mg} \mathrm{kg}^{-1}$ & 0 & 2 & 0.9 & -0.265 & 0.136 & & 0 & 3 & 1.1 & -0.174 & 0.186 \\
\hline Co mg kg ${ }^{-1}$ & 2 & 41 & 14.1 & -0.19 & 0.29 & & 8 & 40 & 19.1 & 0.02 & 0.883 \\
\hline $\mathrm{Cr} \mathrm{mg} \mathrm{kg}^{-1}$ & 8 & 99 & 35.7 & -0.134 & 0.456 & & 11 & 102 & 47.6 & 0.196 & 0.137 \\
\hline $\mathrm{Cu} \mathrm{mg} \mathrm{kg}^{-1}$ & 7 & 58 & 17.8 & -0.076 & 0.661 & & 5 & 96 & 23.7 & 0.036 & 0.786 \\
\hline Fe mg kg ${ }^{-1}$ & 6238 & 50,400 & 24107 & 0.125 & 0.468 & & 7100 & 68,500 & 32144 & 0.171 & 0.196 \\
\hline $\mathrm{K} \mathrm{mg} \mathrm{kg}^{-1}$ & 1646 & 53,983 & 12791 & -0.14 & 0.415 & & 3085 & 27,300 & 11400 & 0.094 & 0.481 \\
\hline $\mathrm{Mg} \mathrm{mg} \mathrm{kg}{ }^{-1}$ & 604 & 8300 & 2560 & $0.440^{* *}$ & 0.007 & & 1021 & 7955 & 3172 & $0.363^{*}$ & $<0.005$ \\
\hline Mn mg kg${ }^{-1}$ & 103 & 8820 & 1696 & -0.097 & 0.572 & & 219 & 7655 & 1775 & -0.318 & 0.014 \\
\hline Mo mg kg-1 & 1 & 9 & 3.9 & 0.049 & 0.777 & & 0 & 10 & 4.3 & -0.334 & 0.01 \\
\hline Na mg kg ${ }^{-1}$ & 306 & 4200 & 1968 & -0.069 & 0.687 & & 566 & 7410 & 2862 & -0.24 & 0.067 \\
\hline Ni mg kg${ }^{-1}$ & 7 & 44 & 23.0 & -0.068 & 0.693 & & 8 & 67 & 25.6 & 0.21 & 0.111 \\
\hline $\mathrm{P} \mathrm{mg} \mathrm{kg}^{-1}$ & 130 & 911 & 436.7 & 0.22 & 0.198 & & 195 & 1218 & 523.5 & -0.088 & 0.506 \\
\hline $\mathrm{Pb} \mathrm{mg} \mathrm{kg}^{-1}$ & 2 & 85 & 28.6 & -0.088 & 0.609 & & 0 & 122 & 27.3 & 0.167 & 0.205 \\
\hline $\mathrm{S}$ mg kg${ }^{-1}$ & 15 & 800 & 178.8 & $0.653^{* *}$ & $<0.001$ & & 10 & 827 & 204.9 & $0.458^{* *}$ & $<0.001$ \\
\hline Se $\mathrm{mg} \mathrm{kg}^{-1}$ & 0 & 37 & 16.5 & -0.002 & 0.992 & & 0 & 43 & 18.8 & $0.284^{*}$ & 0.029 \\
\hline Sr mg kg ${ }^{-1}$ & 12 & 111 & 33.8 & -0.079 & 0.646 & & 20 & 88 & 41.1 & $0.294^{*}$ & 0.024 \\
\hline Ti mg kg ${ }^{-1}$ & 408 & 4200 & 1606 & 0.147 & 0.393 & & 661 & 5000 & 1731.8 & -0.041 & 0.759 \\
\hline $\mathrm{Zn} \mathrm{mg} \mathrm{kg}^{-1}$ & 23 & 120 & 60.2 & 0.242 & 0.155 & & 33 & 325 & 81.8 & 0.227 & 0.084 \\
\hline $\mathrm{C} \mathrm{mg} \mathrm{kg}^{-1}$ & 305 & 3565 & 1237 & $0.814^{* *}$ & $<0.001$ & & 495 & 3010 & 1171.3 & $0.371^{*}$ & 0.004 \\
\hline $\mathrm{N} \mathrm{mg} \mathrm{kg}^{-1}$ & $<50$ & 150 & 66.7 & $0.823^{* *}$ & $<0.001$ & & $<50$ & 150 & 56.7 & 0.041 & 0.758 \\
\hline
\end{tabular}

ICP analysis for total extractable analytes. Number of sampled plots urban $n=9$, rural $n=17$, level. ${ }^{* *}$ Correlation is significant at the 0.01 level. "Correlation is significant at the 0.05 .

the most important species the authors calculated IVs for each species inclusive of relative leaf area and relative abundance. The study reported Fagus grandifolia, Lirodendron spp. and Acer rubum the most important species based on their calculated IVs. Here we assess the most importance species within four distinct quadrants in the city of Knoxville (including a $1.609 \mathrm{~km}$ buffer around the city). Quadrants were designated based on topographic differences in Knox Co. which affects soil composition and water flow. Three species, Acer spp., Pinus spp. 
and Quercus spp. had > 8 occurrences per plot (26-0.04 ha plot) within each quadrant (Table 2). In quadrant one (northeast location) the dominant over-story species were Carya (IV = 108) and Quercus (IV = 33). In quadrant two (southeast location) the dominant over-story species were Juniperus (IV = 69), Pinus (IV = 75), and Quercus (IV = 37). In quadrant three (southwest location) the dominant over-story species were Carya $(\mathrm{IV}=33$ ), Quercus (IV = 61) and Liriodendron (IV = 78). In quadrant four (northwest location) the dominant over-story were Quercus (IV = 26), Prunus (IV = 22) and Acer (IV = 76).

Even though mean species richness was slightly higher in urban (1.51) than rural (1.30) plots, no significantly difference was found. Porter et al. (2001), studied six specific sites (a preserve, a recreational area, a golf course, a residential subdivision, apartment complexes, and a business district) in Oxford, $\mathrm{OH}$ along a forest-to-urban gradient. Their study found that in urban areas species richness was greater $H^{\prime}=2.69$ (residential), 2.19 (apartment), 2.06 (business districts) than in natural sites with $H^{\prime}=2.30$ (golf course), 1.94 (recreational areas) and 1.70 (preserves). Our study did not inventory commercial, business or recreational areas within the City of Knoxville. We focused on natural forest patches within residential areas, with minimal to no human interaction. McKinney (2008) reviewed 105 studies on the effects of urbanization on species richness of non-avian species and plants. He found that for all groups species richness tends to be reduced in areas with extreme urbanization whereas species richness varies significantly as you move away from central urban core areas.

We tested whether tree diversity affected the quantitative change in soil microbial biomass carbon (MBC) and microbial biomass nitrogen (MBN) among sampled plots by season (fall, summer, winter and spring) and location (urban versus rural). Our study quantitatively assessed MBC and MBN spatially (urban and rural) and temporally (summer, fall, winter and spring) in the City of Knoxville from May 2012 to May 2013. In comparing MBC between urban and rural plots, there was no significant difference. There are several possibly explanations 1) soils may contain similar quantities of labile and passive carbon pools, 2) residential urban and rural soils have similar capacities in terms of carbon sequestration and cycling or 3) soil carbon pools in residential rural plots are impacted by urbanization and environmental changes as much as residential urban plots (Pouyat et al., 2002). Pouyat et al. (2002) studied the potential effects of urbanization on soil organic carbon (SOC) in the City of Baltimore, MD. They found that along an urban-to-rural gradient soil organic carbon was significantly higher in urban forest stands than suburban and rural stands. Groffman et al. (1995) compared carbon pools along the urban-rural gradient and found that urban areas contained more passive pools of carbon; therefore, lower MBC could be expected due to the longer turnover rate for $\mathrm{C}$ mineralization. Overall, this study points to the heterogeneity of soils and their functions, especially in and around urban fringes.

MBN means did differ by location, mean rural MBN was $3.2 \mathrm{~g} \mathrm{~N} \mathrm{~m}^{-2}$ compared to a mean urban MBN of 2.0

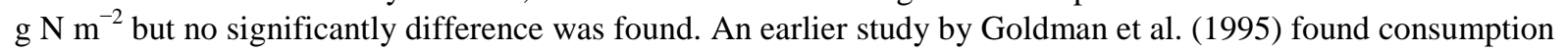
rates higher for soil $\mathrm{NH}_{4}^{+}$and total inorganic $\mathrm{N}$; therefore both showing lower concentrations at $(p<0.05)$ in urban areas than in rural areas along a urban-rural transect from highly urbanized Bronx County, NY to rural Litchfield County, CT. These consumption rates were lower for soil $\mathrm{NO}_{3}^{-}$with higher concentration rates at ( $p$ $<0.05$ ) in urban areas than in rural areas. Raciti et al. (2008) estimated the production and consumption of $\mathrm{NO}_{3}^{-}$to $\mathrm{NH}_{4}^{+}$to assess differences in internal nitrogen cycling under the two vegetation types, urban lawns and forests. They found higher turnover rates of $\mathrm{N}$ retention in urban lawns than forests, but no deference in the MBN even though there was twice the amount of $\mathrm{N}$ retention in urban lawns than forests. Zhu \& Carreiro (2004) found that there were higher turnover rates of $\mathrm{N}$ in urban areas which caused increased $\mathrm{N}$ mineralization when compared to rural areas. The landscape age could also be a potential driver for the lower MBN in the urban residential plots. Scharenbroch et al. (2005) found that new residential landscapes had lower MBN than old residential landscapes. In residential urban and rural plots sampled throughout the City of Knoxville urban plots had a more recent disturbance history as compared to rural plots. The rural plots therefore have had time to establish microbial populations and undergo ecological succession. One possible explanation for the lower MBN in the urban sites is that increased amounts of earthworms could contribute to lower MBN as well as lower quality leaf litter (Zhu \& Carreiro, 2004). Additionally, increased fertilization rates have been found to decrease microbial C and $\mathrm{N}$ in northern hardwood forests, which is likely due to large quantities of $\mathrm{N}$ in the soil and faster microbial turnover rates (Fisk \& Fahey, 2001).

The biogeochemical interactions in soil habitats are composed of connecting organic, inorganic and biological factors that influence each other and interact in soil ecosystems (Totsche et al., 2009). Our soils contained twenty three elements and trace metals; of which $\mathrm{Pb}$, and macronutrients $\mathrm{S}, \mathrm{Mg}$, and $\mathrm{Ca}$, were significantly correlated $(p<0.05)$, with MBN and MBC. MBC in rural residential plots were significantly correlated $(p<0.05)$ with S, 
Mg, and Ca and significantly correlated $(p<0.1)$ urban plots. A field study in Spain's temperate zone found when soils exhibited increases in MBC and flux of Mg (Diaz-Ravina et al., 1992), soil microbes are a component mediating soil Mg levels. In metropolitan Beijing, concentrations of Mg and Ca did not vary between park, industrial, residential, agricultural, traffic, and public soils (Wang et al., 2011); Mg and Ca could be influenced by fluxes in MBC regardless of location.

Interestingly, there was a significant correlation $(p<0.05)$ between MBN and $\mathrm{Pb}$ in rural residential plots. In Aberdeen city, Scotland, UK and rural agricultural fields in the vicinity of Aberdeen city, Yuangen et al. (2006) found that the elements $\mathrm{Pb}$ and $\mathrm{Zn}$ had different accumulations in the urban soils compared with rural soil. Contents of $\mathrm{Pb}$ and other metals were significantly higher in urban soils (roadside soils and parkland soils) than in rural soils $(p<0.05)$. Pouyat \& McDonnell (1991) found variation in the concentration of metals $(\mathrm{Pb}$ and $\mathrm{Cu})$ along an urban-rural gradient in southern New York, being generally higher closer to the urban core of the transect line and decreasing as you moved out from the urban core. The elements $\mathrm{Pb}$ and $\mathrm{Zn}$ are known to be anthropogenic pollutants in urban environment. Yuangen et al. (2006) suggests that microbial biomass may be the most sensitive indicator to metal $\mathrm{Pb}$ inputs in soil.

Rural residential plots were found to have a higher CEC than urban plots indicating higher fertility and nutrient exchange in forests as one move along an urban-to-rural gradient. Interestingly, this suggests that MBC should also be higher in rural residential plots based off findings from an urban soils study (Ohya et al., 1988). MBC along the urban-rural gradient, however, did not follow the pattern of CEC being higher in rural and lower in urban residential plots. Instead of MBC differing along the urban-rural gradient by location, it proved to differ significantly between the summer and winter; whereas MBN differed only by location and not by season. MBN has been found to increase in the spring along the urban-rural gradient of New York City from microbes utilizing inorganic $\mathrm{N}$ that was stored throughout winter (Zhu \& Carreiro, 2004). Our plots did not exhibit this spring MBN flux. In a seasonal turf grass study, MBC and MBN were found to be lowest in September and the highest in December (Yao, 2011). Following the pattern of urban-to-rural plots in regards to the seasons for MBC. Since MBC accounts for a portion of TOC, MBC can be positively related to the amount of SOM (Jenkinson \& Ladd, 1981). This would explain the elevated MBC during the winter season due to leaf litter accumulation on the forest floors combined with decomposition occurring throughout the fall. Indicating though the urban-rural gradient is subject to urban environmental stressors, the urban ecosystem is resilient in maintaining the ecosystem functions of more natural systems.

\section{Conclusion}

In determining tree species diversity and soil composition along an urban-to-rural gradient in residual forest patches and open field, it was found that tree diversity did not differ significantly for residential urban/rural plots in Knoxville, Tennessee. The diversity of Knoxville's urban forest is relatively resilient to the presses of different levels of land use/land change. Spatial (urban/rural) and temporal differences were identified for chemical, physical and biological soil properties along an urban-to-rural gradient. Chemically, residual forest patches along the urban-to-rural gradient were found to be negatively correlated, both in urban and rural; with Barium and Cobalt. In both locations soil solution mean concentrations were approximated at $280 \mu \cdot \mathrm{g}^{-1} \mathrm{Ba}$ and $20 \mu \cdot \mathrm{g}^{-1}$ Co. Other elements negatively correlated with tree diversity were Potassium and Copper for urban plots and Manganese, Zinc and Chromium in rural plots. Similarly, physical soil properties such as bulk density in both urban and rural sites were negatively correlated with tree diversity. Both land use types had mean density of $1.05 \mathrm{~g} / \mathrm{m}^{3}$ which is typical for natural forest soils and indicates that Knoxville's residual forest are minimally impacted by continual land use changes often found in the urban ecosystem.

Rural soils did differ physically from urban soil, in cation exchange capacity (CEC) and soil moisture content (GSM). Both were positively correlated with tree diversity and rural residential plots were found to have a higher CEC than urban plots indicating higher fertility and nutrient exchange in forests as one move along an urbanto-rural gradient. Biologically, there was no indication that soils were affected by tree diversity, in terms of soil microbial biomass $\mathrm{C} / \mathrm{N}$ along an urban-to-rural in Knoxville residential plots.

When determining the impacts of land-use change from urban to rural on tree diversity and soil biological, chemical, and physical properties within urban residual forest patches it was found that chemical soil concentrations differed seasonal and by location along the urban-to rural gradient. Distance from city center along an urban-to-rural gradient for MBC by location did differ significantly between the summer and winter; whereas 
MBN differed only by location and not by season. The principal component analyses (PCA) indicated that the variation along the gradient was mostly due to the soil chemical properties as compared to the physical and biological properties. The distances from city center and tree diversity were not significant in the loading values for the PCA. Residual forest patches and open fields of residential land use in the city of Knoxville function similarly to natural vegetative areas. Characterizing residual forest patches and open fields in residential areas has the potential to promote different land use and land change practices. Utilizing the chemical, physical and biological soil characteristics and tree diversity in the development of a predictive model for residual forest patches or open field based on urban or rural location can provide a tool for development in terms of residential land use. Though the predictive model developed for the city of Knoxville indicates the predicted value of Distance $=$ $12.009+0.390 \pm 0.005 \mathrm{Bappm}-282 \pm 0.037 \mathrm{Sr}$ ppm can be used to estimate/designate whether a location is urban or rural, further data mining is suggested to further improve the models accuracy and capabilities. Through the understanding of how urban ecosystems work as well as the functions forest patches and open spaces provide; city manager can offer residents higher quality urban environments.

\section{Acknowledgements}

We thank the property owners of the City and County of Knoxville, TN for allowing access to conduct the research on their properties. Additionally, we thank the Departments of Forestry, Wildlife and Fisheries and Biosystems Engineering and Soil Science.

\section{References}

Alig, R. J., \& Plantinga, A. J. (2004). Future Forestland Area: Impacts from Population Growth and Other Factors That Affect Land Values. Journal of Forestry, 102, 19-24.

Aon, M. A., Sarena, D. E., Burgos, J. L., \& Cortassa, S. (2001). Microbiological, Chemical and Physical Properties of Soils Subjected to Conventional or No-Tillage Management: An Assessment of Their Quality Status. Soil Till Resources, 60, 173-186. http://dx.doi.org/10.1016/S0167-1987(01)00190-8

Baumgartl, Th. (1998). Physical Soil Properties in Specific Fields of Application Especially in Anthropogenic Soils. Soil Till Resources, 47, 51-59. http://dx.doi.org/10.1016/S0167-1987(98)00072-5

Beck, T., Joergensen, R. G., Kandeler, E., Makeschin, F., Nuss, E., Oberholzer, H. R., \& Scheu, S. (1997). An Inter-Laboratory Comparison of Ten Different Ways of Measuring Soil Microbial Biomass C. Soil Biology and Biochemistry, 29, 1023-1032. http://dx.doi.org/10.1016/S0038-0717(97)00030-8

Brookes, P. C., Landman, A., Pruden, G., \& Jenkinson, D. S. (1985). Chloroform Fumigation and the Release of Soil Nitrogen: A Rapid Direct Extraction Method to Measure Microbial Biomass Nitrogen in Soil. Soil Biology and Biochemistry, 17, 837-842. http://dx.doi.org/10.1016/0038-0717(85)90144-0

Certini, G. (2005). Effects of Fire on Properties of Forest Soils: A Review. Oecologia, 143, 1-10. http://dx.doi.org/10.1007/s00442-004-1788-8

Chapman, H. D. (1965). Cation-Exchange Capacity. P. 891-901. In C. A. Black et al. (Eds.), Methods of Soil Analysis, Chemical and Microbiological Properties (pp. 891-901). Madison, WI: ASA.

Craul, P. J. (1999). Urban Soils: Applications and Practices. New York: Wiley.

Curtis, J. T., \& McIntosh, R. P. (1951). An Upland Forest Continuum in the Prairie-Forest Border Region of Wisconsin. Ecology, 31, 476-496. http://dx.doi.org/10.2307/1931725

Deaderick, L. (1976). Heart of the Valley: A History of Knoxville, Tennessee. Knoxville, TN: The East Tennessee Historical Society.

Dick, R. P. (1994). Soil Enzyme Activities as Indicators of Soil Quality. In Defining Soil Quality for a Sustainable Environment (pp. 107-124). Madison, WI: SSSA, Special Publication No. 35.

Dwyer, J. F., Nowak, D. J., Noble, M. H., \& Sisinni, S. M. (2000). Assessing Our Nation's Urban Forest: Connecting People with Ecosystems in the 21st Century. General Technical Report PNW-490, Portland, OR: USDA Forest Service.

Fierer, N., Schimel, J. P., \& Holden, P. A. (2003). Variations in Microbial Community Composition through Two Soil Depth Profiles. Soil Biology and Biochemistry, 35, 167-176. http://dx.doi.org/10.1016/S0038-0717(02)00251-1

Fisk, M. C., \& Fahey, T. J. (2001). Microbial Biomass and Nitrogen Cycling Responses to Fertilization and Litter Removal in Young Northern Hardwood Forests. Biogeochemistry, 53, 201-223. http://dx.doi.org/10.1023/A:1010693614196

Girvan, M. S., Bullimor, J., Pretty, J. N., Osborn, A. M., \& Ball, A. S. (2003). Soil Type Is the Primary Determinant of the Composition of the Total and Active Bacterial Communities in Arable Soils. Applied and Environmental Microbiology, 69, 
1800-1809. http://dx.doi.org/10.1128/AEM.69.3.1800-1809.2003

Groffman, P. M., Pouyat, R. V., McDonnell, M. J., Pickett, S. T. A., \& Zipperer, W. C. (1995). Carbon Pools and Trace Gas Fluxed in Urban Forest Soils. In R. Lat, J. Kimble, E. Levine, \& B. A. Steward (Eds.), Advances in Soil Science, Soil Management and Greenhouse Effect (pp. 147-158). Boca Raton, FL: CRC Press, Inc.

Hampson, P. S., Treece Jr., M. W., Johnson, G. C., Ahlstedt, S. A., \& Connell, J. F. (2000). Water Quality in the Upper Tennessee River Basin, Tennessee, North Carolina, Virginia, and Georgia 1994-98. http:/pubs.usgs.gov/circ/circ1205/

Hart, S. C., Stark, J. M., Davidson, E. A., \& Firestone, M. K. (1994). Nitrogen Mineralization, Immobilization, and Nitrification. In R. V. Weaver et al. (Eds.), Methods of Soil Analysis, Part 2, SSA Book Series 5 (pp. 985-1018). Madison, WI: SSSA.

Hartgrove, N. R. (2004). Soil Survey of Knox County, Tennessee (pp. 1-3). Washington DC: Natural Resources Conservation Service.

Ibekwe, A. M., Watt, P. M., Grieve, C. M., Sharma, V. K., \& Lyons, S. R. (2002). Multiplex Fluorgenic Real-Time PCR for Detection and Quantification of Escherichia coli O157:H7 in Dairy Wastewater Wetlands. Applied and Environmental Microbiology, 68, 4853-4862. http://dx.doi.org/10.1128/AEM.68.10.4853-4862.2002

Jenkinson, D. S., \& Ladd, J. N. (1981). Microbial Biomass in Soil: Measurement and Turnover. In E. A. Paul, \& J. N. Ladd (Ed.), Soil Biochemistry (Vol. 5, pp. 415-471).

Jim, C. Y. (1998). Soil Characteristics and Management in an Urban Park in Hong Kong. Environmental Management, 22, 683-695. http://dx.doi.org/10.1007/s002679900139

Kent, M., \& Coker, P. (1992). Vegetation Description and Analysis: A Practical Approach (pp. 167-169). New York: John Wiley and Sons.

Knoxville and Knox County Planning Commission (1988). The Future of Our Past: Historic Sites Survey and Cultural Resources Plan for Knoxville and Knox County Tennessee. Knoxville, Tenn: The Commission.

Larson, W. E., \& Pierce, F. J. (1994). The Dynamics of Soil Quality as a Measure of Sustainable Management, In Defining Soil Quality for a Sustainable Environment. SSSA Special Publication 35, Soil Science Society of America and American Society of Agronomy, 37-51.

McKinney, M. (2008). Effects of Urbanization on Species Richness: A Review of Plants and Animals. Urban Ecosystems, 11, 161-176. http://dx.doi.org/10.1007/s11252-007-0045-4

Neary, D., Klopatek, C., DeBano, L., \& Ffolliott, P. (1999). Fire Effects on Belowground Sustainability: A Review and Synthesis. Forest Ecology and Management, 122, 51-71. http://dx.doi.org/10.1016/S0378-1127(99)00032-8

Nowak, D. J. (2002). The Effects of Urban Trees on Air Quality. USDA Forest Service. www.nrs.fs.fed.us/units/urban/local-resources/downloads/Tree Air Qual.pdf

Nowak, D. J., \& Greenfield, E. J. (2012). Tree and Impervious Cover Change in U.S. Cities. Urban Forestry \& Urban Greening, 11, 21-30. http://dx.doi.org/10.1016/j.ufug.2011.11.005

Nowak, D. J., Cumming, A. B., Twardus, D., Hoehn III, R. E., Oswalt, C. M., \& Brandeis, J. T. (2011). Urban Forests of Tennessee, 2009. General Technical Report SRS-149, Asheville, NC: U.S. Department of Agriculture Forest Service, Southern Research Station.

Nowak, D. J., Hoehn, R. E., Crane, D. E., Stevens, J. C., \& Walton, J. T. (2006a). Assessing Urban Forest Effects and Values. USDA Forest Service. http://www.fs.fed.us/pnw/about/arra/pdfs/Mills\%20fact\%20sheet.pdf

Ohya, H., Fujiwara, S., Komai, Y., \& Yamaguchi, M. (1988). Microbial Biomass and Activity in Urban Soils Contaminated with Zn and Pb. Biology and Fertility of Soils, 6, 9-13. http://dx.doi.org/10.1007/BF00257913

Patterson, J. C., Murray, J. J., \& Short, J. R. (1980). The Impact of Urban Soils on Vegetation. METRIA: 3, Proceedings of the Third Conference of the Metropolitan Tree Improvement Alliance, Rutgers, New Brunswick, 18-20 June 1980.

Pickett, S. T. A., Cadenasso, M. L., Grove, J. M., Boone, C. G., Goffman, P. M., Irwin, E., Kaushal, S. S., Marshall, V., McGrath, B. P., Nilon, C. H., Pouyat, R. V., Szlavecz, K., Troy, A., \& Warren, P. (2001). Urban Ecological Systems: Scientific Foundations and a Decade of Progress. Journal of Environmental Management, 92, 331-362.

http://dx.doi.org/10.1016/j.jenvman.2010.08.022

Porter, E. E., Forschner, B. R., \& Blair, R. B. (2001). Woody Vegetation and Canopy Fragmentation along a Forest-to-Urban Gradient. Urban Ecosystems, 5, 131-151. http://dx.doi.org/10.1023/A:1022391721622

Pouyat, R. V., \& Effland, W. R. (1999). The Investigation and Classification of Humanly Modified Soils in the Baltimore Ecosystem Study. In J. M. Kimble, R. J. Ahrens, \& R. B. Bryant (Eds.), Classification, Correlation, and Management of Anthropogenic Soils (pp. 141-154). Lincoln, NE: USDA Natural Resource Conservation Service, National Soil Survey Center.

Pouyat, R. V., \& McDonnell, M. J. (1991). Heavy Metal Accumulation in Forest Soils along an Urban-Rural Gradient in Southeastern New York, USA. Water, Air, and Soil Pollution, 57-58, 797-807. http://dx.doi.org/10.1007/BF00282943 
Pouyat, R. V., Szlavecz, K., Yesilonis, I. D., Groffman, P. M., \& Schwarz, K. (2010). Chemical, Physical and Biological Characteristics of Urban Soils. Urban Ecosystem Ecology, 55, 119-151.

Pouyat, R. V., Yesilonis, I. D., Russell-Anelli, J., \& Neerchal, N. K. (2007). Soil Chemical and Physical Properties that Differentiate Urban Land-Use and Cover Types. Soil Science Society of America Journal, 71, 1010-1019.

Pouyat, R., Groffman, P., Yesilonis, I., \& Hernandez, L. (2002). Soil Carbon Pools and Fluxes in Urban Ecosystems. Environmental Pollution, 116, S107-S118. http://dx.doi.org/10.1016/S0269-7491(01)00263-9

Raciti, S. M., Groffman, P. M., \& Fahey, T. J. (2008). Nitrogen Retention in Urban Lawns and Forests. Ecological Society of America. Ecological Applications, 18, 1615-1626. http://dx.doi.org/10.1890/07-1062.1

Riemann, R. (2003). Pilot Inventory of FIA Plots Traditionally Called “Nonforest”. General Technical Report NE-312, Newton Square, PA: USD A Northeastern Research Station.

Scharenbroch, B. C., Lloyd, J. E., \& Johnson-Maynard, J. L. (2005). Distinguishing Urban Soils with Physical, Chemical, and Biological Properties. Pedobiologia, 49, 283-296. http://dx.doi.org/10.1016/j.pedobi.2004.12.002

Shannon, C. E., \& Weaver, W. (1949). The Mathematical Theory of Communication (pp. 1-117). Urbana, IL: The University of Illinois Press.

Short, J. R., Fanning, D. S., Foss, J. E., \& Patterson, J. C. (1986a). Soils of the Mall in Washington DC: I. Statistical Summary of Properties. Soil Science Society of America Journal, 50, 699-705. http://dx.doi.org/10.2136/sssaj1986.03615995005000030030x

Singh, J. S., Raghubanshi, A. S., Singh, R. S., \& Srivastava, S. C. (1989). Microbial Biomass Acts as a Source of Plant Nutrients in Dry Tropical Forest and Savanna. Nature, 338, 499-500. http://dx.doi.org/10.1038/338499a0

Totsche, K. U., Rennert, T., Gerzabek, M. H., Kogel-Knabner, I., Smalla, K., Spiteller, M., \& Vogel, H. J. (2009). Biogeochemical Interfaces in Soil: The Interdisciplinary Challenge for Soil Science. Journal of Plant Nutrition and Soil Science, 173, 88-99. http://dx.doi.org/10.1002/jpln.200900105

Wang, M., Markert, B., Shen, W., Chen, W., Peng, C., \& Ouyang, Z. (2011). Microbial Biomass Carbon and Enzyme Activities of Urban Soils in Beijing. Environmental Science and Pollution Research, 18, 958-967. http://dx.doi.org/10.1007/s11356-011-0445-0

Yuangen, Y., Campbell, C. D., Clark, L., Cameron, C. M., \& Paterson, E. (2006). Microbial Indicators of Heavy Metal Contamination in Urban and Rural Soils. Chemosphere, 63, 1942-1952. http://dx.doi.org/10.1016/j.chemosphere.2005.10.009

Zak, D. R., Holmes, W. E., White, D. C., Peacock, A. D., \& Tilman, D. (2003). Plant Diversity: Soil Microbial Communities and Ecosystem Function, Are There Any Links? Ecology, 84, 2042-2050. http://dx.doi.org/10.1890/02-0433

Zhu, W. X., \& Carreiro, M. M. (2004). Temporal and Spatial Variations in Nitrogen Transformations in Deciduous Forest Ecosystems along an Urban-Rural Gradient. Soil Biology and Biochemistry, 36, 267-278.

http://dx.doi.org/10.1016/j.soilbio.2003.09.013 
Scientific Research Publishing (SCIRP) is one of the largest Open Access journal publishers. It is currently publishing more than 200 open access, online, peer-reviewed journals covering a wide range of academic disciplines. SCIRP serves the worldwide academic communities and contributes to the progress and application of science with its publication.

Other selected journals from SCIRP are listed as below. Submit your manuscript to us via either submit@scirp.org or Online Submission Portal.
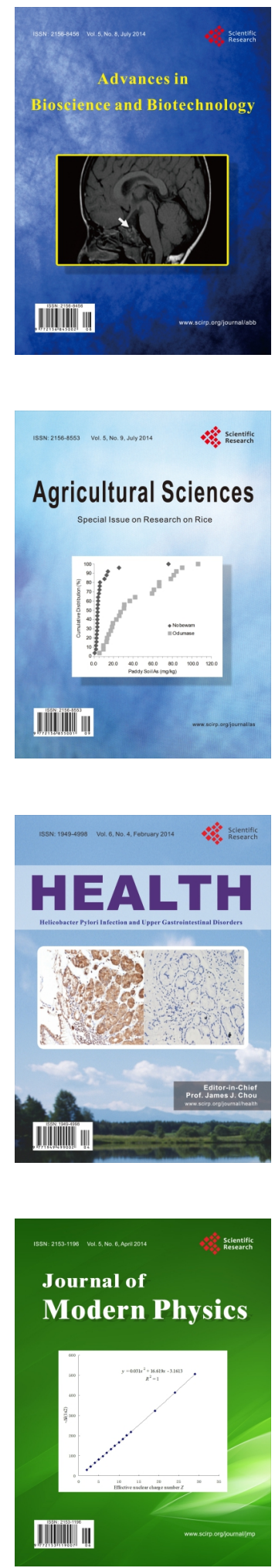
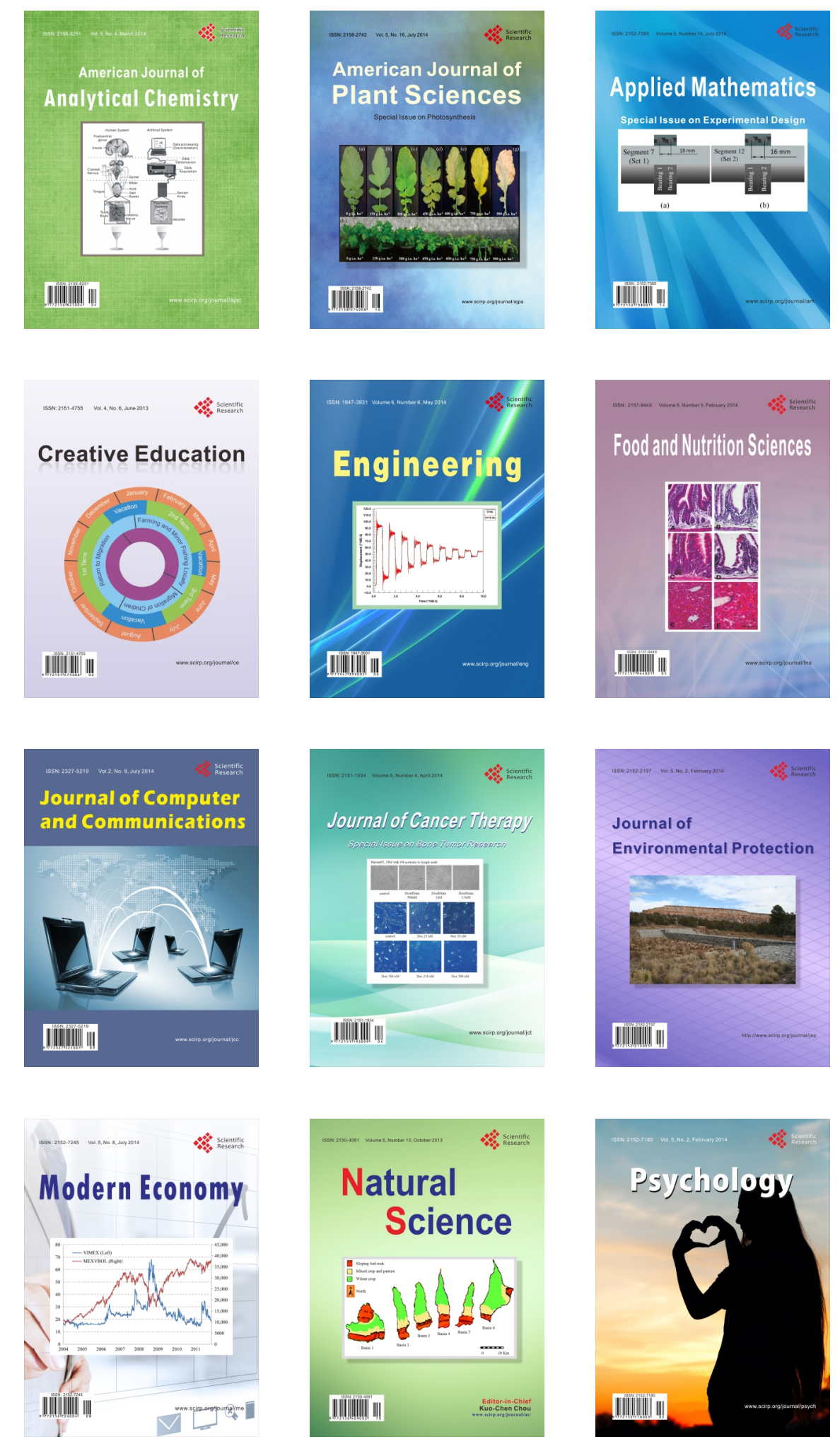